\title{
Maternal diabetes promotes mTORC1 downstream signalling in rabbit preimplantation embryos
}

\author{
Jacqueline Gürke, Maria Schindler, S Mareike Pendzialek, René Thieme, Katarzyna J Grybel, \\ Regine Heller ${ }^{1}$, Katrin Spengler ${ }^{1}$, Tom P Fleming ${ }^{2}$, Bernd Fischer and Anne Navarrete Santos
}

Department of Anatomy and Cell Biology, Faculty of Medicine, Martin Luther University Halle-Wittenberg, Grosse Steinstrasse 52, D-06097 Halle (Saale), Germany, ${ }^{1}$ Institute of Molecular Cell Biology, Center for Molecular Biomedicine, Hans-Knoell-Straße 2, D-07745 Jena, Germany and ${ }^{2}$ Centre for Biological Sciences, Southampton General Hospital, University of Southampton, Mailpoint 840, Tremona Road, Southampton SO16 6YD, UK

Correspondence should be addressed to J Gürke; Email: jacqueline.guerke@medizin.uni-halle.de

\begin{abstract}
The mammalian target of rapamycin complex 1 (mTORC1) is known to be a central cellular nutrient sensor and master regulator of protein metabolism; therefore, it is indispensable for normal embryonic development. We showed previously in a diabetic pregnancy that embryonic mTORC1 phosphorylation is increased in case of maternal hyperglycaemia and hypoinsulinaemia. Further, the preimplantation embryo is exposed to increased L-leucine levels during a diabetic pregnancy. To understand how mTOR signalling is regulated in preimplantation embryos, we examined consequences of L-leucine and glucose stimulation on mTORC1 signalling and downstream targets in in vitro cultured preimplantation rabbit blastocysts and in vivo. High levels of L-leucine and glucose lead to higher phosphorylation of mTORC1 and its downstream target ribosomal S6 kinase 1 (S6K1) in these embryos. Further, L-leucine supplementation resulted in higher embryonic expression of genes involved in cell cycle (cyclin D1; CCND1), translation initiation (eukaryotic translation initiation factor 4E; EIF4E), amino acid transport (large neutral amino acid transporter 2; Lat2: gene SLC7A8) and proliferation (proliferating cell nuclear antigen; PCNA) in a mTORC1-dependent manner. Phosphorylation of S6K1 and expression patterns of CCND1 and EIF4E were increased in embryos from diabetic rabbits, while the expression of proliferation marker PCNA was decreased. In these embryos, protein synthesis was increased and autophagic activity was decreased. We conclude that mammalian preimplantation embryos sense changes in nutrient supply via mTORC1 signalling. Therefore, mTORC1 may be a decisive mediator of metabolic programming in a diabetic pregnancy.

Reproduction (2016) 151 465-476
\end{abstract}

\section{Introduction}

The mammalian target of rapamycin (mTOR) is a serine/threonine protein kinase and is evolutionarily conserved from yeast to human. mTOR acts as a central regulator in signalling pathways involved in the control of cell growth, proliferation and metabolism by transducing environmental and cellular stimuli (Shamji et al. 2003, Wullschleger et al. 2006). mTOR interacts with other proteins to build two multiprotein complexes: mTOR complex 1 (mTORC1) and mTOR complex 2 (mTORC2) (Wullschleger et al. 2006, Zoncu et al. 2011). In addition to different rapamycin sensitivities, both mTOR complexes differ in activation and substrate regulation and in involved biological processes (Laplante \& Sabatini 2009).

Rapamycin is a specific, potent and allosteric inhibitor of mTORC1. Under normal conditions, mTORC1 is constitutively activated by the presence of growth factors and nutrients. Additionally, mTORC1 signalling is regulated by cellular energy status, oxygen, genotoxic stress and amino acids (reviewed by Yang et al. (2008)). Activated mTORC1 promotes protein synthesis and lipid biogenesis. Especially, branched chain amino acids (BCAA) availability, with leucine as the most potent mTORC1 activator, regulates mTOR signalling and protein metabolism (Kimball \& Jefferson 2006).

Previous studies indicated mTORC1 involvement in early embryo development and implantation. Already in 2001, Martin and Sutherland showed that exogenous amino acids induce mTORC1-dependent S6K1 phosphorylation leading to the translation of proteins required for trophoblast differentiation and the initiation of implantation (Martin \& Sutherland 2001). In the mouse, a disruption of the Mtor gene resulted in early embryo lethality (E 5.5) (Gangloff et al. 2004). A maternal low-protein diet in mice led to decreased amino acid levels combined with reduced embryonic mTORC1 signalling (E 3.5) (Eckert et al. 2012). 
These findings suggest an essential role of mTORC1 in early embryo growth and development.

Protein synthesis is controlled by the eukaryotic initiation factor 4E (EIF4E)-binding protein 1 (4E-BP1) and p70 ribosomal S6 kinase 1 (p70S6K1) (Lin et al. 1994, Pause et al. 1994). Phosphorylation of 4E-BP1 blocks its binding to EIF4E and enables EIF4E to promote cap-dependent translation (reviewed by Richter \& Sonenberg (2005)). The activation of p70S6K1 by $\mathrm{mTORC1}$ leads to a rise in mRNA biogenesis, capdependent translation and elongation and translation of ribosomal proteins (reviewed by Ma \& Blenis (2009)).

mTORC1 promotes anabolism and blocks catabolism, the latter by repressing autophagy through phosphorylation of the ULK complex under nutrient-enriched conditions (Hosokawa et al. 2009). mTORC1 is the key component regulating the balance between growth and autophagy in response to physiological cellular conditions and environmental stress. Autophagy is an evolutionary highly conserved programmed degradation system with the basic role to recycle amino acids, glucose and fatty acids for the generation of energy and to maintain cellular homeostasis. This process has been shown to be critical for oocyte-to-embryo transition and differentiation (Stitzel \& Seydoux 2007) and cell survival during embryo development (Tsukamoto et al. 2008, Singh et al. 2009). Maternal proteins in oocytes are degraded, and new proteins encoded by the zygotic genome are synthesised. Autophagy is triggered by fertilization and up-regulated in early mouse embryos. Mice oocytes with deficiency of autophagy fail to develop beyond the 4- and 8-cell stage (Tsukamoto et al. 2008).

Discoveries over the last decade showed that enhanced mTORC1 signalling is associated with diseases like cancer, obesity and type 2 diabetes (Shwa \& Cantley 2006, Zoncu et al. 2011). Animal experiments documented a higher activation of mTORC1 signalling in liver and skeletal muscle of obese rats (Khamzina et al. 2004). Increased amino acid levels revealed the most activating effects on mTORC1 leading to higher protein synthesis in hepatic rat cells (Dennis et al. 2011). However, nothing is known about the effect of maternal diabetes on embryonic mTORC1 signalling during early pregnancy. Therefore, we have analysed the mTORC1 signalling pathway in response to hyperaminoacidaemia created in vitro and both hyperaminoacidaemia and hyperglycaemia in vivo caused by an induced maternal diabetes mellitus type 1 in rabbit preimplantation embryos.

\section{Materials and methods}

\section{Animals, embryo recovery and in vitro culture}

Alloxan treatment

Experimental insulin-dependent diabetes (IDD) was induced by alloxan (Sigma-Aldrich) treatment, as described before (Ramin et al. 2010). Rabbits were held in single cage with chiaroscuro rhythm of 12:12 $\mathrm{h}$ and were fed ad libitum with customary food (REIKA, Reinsdorf, Germany). The blood glucose levels were monitored twice per day and were kept in a range between 20 and $30 \mathrm{mmol} / \mathrm{l}$. Ketoacidosis was prevented by regular insulin supplementation three times per day (Huminsulin basal (NPH), Lilly Deutschland $\mathrm{GmbH}$, Giessen, Germany). All animal experiments were performed in accordance with the principles of laboratory animal care and had been approved by the local ethics committee (Landesverwaltungsamt Dessau, reference number 42502-2-812). Alloxan injection $(120 \mathrm{mg} / \mathrm{kg}$ body weight) was performed under Ketanest (15 mg/kg body weight; Pfizer) and Dorbene $(0.25 \mathrm{mg} / \mathrm{kg}$ body weight; Zoetis, Berlin, Germany) anaesthesia, and all efforts were made to minimise suffering.

\section{Embryo recovery}

Follicle growth was stimulated in mature female rabbits, outbred ZIKA-hybrid New Zealand Whites purchased from a local breeder (12-16 weeks old; $\sim 3.5 \mathrm{~kg}$ ), by s.c. injection of 110 IU pregnant mare serum gonadotrophin (PMSG; Intervet, Unterschleissheim, Germany) 3 days prior to mating. After mating with fertile males, $75 \mathrm{IU}$ human choriogonadotropin (hCG; Intervet) was intravenously injected to ensure ovulation. In total, 6 days after mating, blastocysts were collected from diabetic and healthy rabbits. The rabbits were sacrificed by an overdose of pentobarbital (Sigma-Aldrich) and exsanguination.

For an ontogenetic comparison, embryos were flushed from the oviducts or uteri on days 3, 4 and 6 post coitum (p.c.), washed two times in basal synthetic medium II (BSM II, serum and growth factor-free) (Maurer 1978), pooled and randomly divided amongst the experimental groups. The blastocysts were characterised morphologically and grouped by gastrulation stages $(0=$ non-gastrulating, $1=$ gastrulation stage with anterior marginal crest and $2=$ gastrulation stage with posterior gastrulation extension) (Fischer et al. 2012). Blastocysts of gastrulation stage 1 were used for in vitro culture experiments and gastrulation stage 2 for in vivo analyses.

The extracellular coverings were removed mechanically for RNA isolation. The embryos were washed three times in PBS containing $0.05 \%$ polyvinyl alcohol (PVA; w/v). The embryos were stored in PBS at $-80^{\circ} \mathrm{C}$ until RNA isolation for RT-qPCR. For western Blot analysis, embryos were washed three times in PBS and the extracellular coverings were removed mechanically in $0.05 \%$ PVA/PBS $(\mathrm{w} / \mathrm{v})$ containing protease and phosphatase inhibitor. Samples of whole embryos or separated embryoblast and trophoblast cells were pooled in RIPA buffer with protease and phosphatase inhibitor and stored at $-80^{\circ} \mathrm{C}$ until further processing.

\section{Sample allocation}

Sample allocation and experimental schedule was performed as illustrated in Table 1. A total of 332 blastocysts from 9 diabetic (D1 to D3) and 24 non-diabetic rabbits (C1 to C6) was analysed (Table 1). Six days after mating, several diabetic and/or non-diabetic rabbits were killed. RNA samples were collected from single blastocysts. For protein analyses, a pool of seven or more embryos from different rabbits was used. All in vitro and in vivo experiments were repeated at least three 
Table 1 Sample allocation and experimental schedule.

\begin{tabular}{|c|c|c|c|c|c|c|c|c|c|}
\hline \multirow[b]{2}{*}{ Experiment $^{\mathrm{a}}$} & \multicolumn{3}{|c|}{ Diabetic rabbits (D) } & \multicolumn{6}{|c|}{ Non-diabetic rabbits (controls, C) } \\
\hline & D1 & D2 & D3 & $\mathrm{C} 1$ & $\mathrm{C} 2$ & $\mathrm{C} 3$ & $\mathrm{C} 4$ & C5 & C6 \\
\hline Number of animals & 3 & 3 & 3 & 2 & 2 & 2 & 6 & 6 & 6 \\
\hline \multicolumn{10}{|l|}{ Embryo numbers and distribution } \\
\hline \multicolumn{10}{|l|}{ Transcription analysis } \\
\hline Whole blastocysts & 3 & 3 & 4 & 3 & 3 & 4 & - & - & - \\
\hline Separated embryoblast and trophoblast & 3 & 4 & 4 & 5 & 6 & 6 & - & - & - \\
\hline In vitro culture & - & - & - & - & - & - & 15 & 20 & 15 \\
\hline \multicolumn{10}{|l|}{ Protein analysis } \\
\hline Whole blastocysts & 7 & 8 & 8 & 7 & 8 & 7 & 7 & - & - \\
\hline In vitro culture & - & - & - & - & - & - & 50 & 50 & 50 \\
\hline Protein synthesis & 2 & 2 & 2 & 2 & 2 & 2 & - & - & - \\
\hline Staining of lysosomes & 3 & 3 & 4 & 3 & 3 & 4 & - & - & - \\
\hline
\end{tabular}

${ }^{\text {a}}$ Experiments with same number: animals were handled in parallel regarding mating and embryo collection at day 6 post coitum.

times. After finishing all experiments, the frozen samples were commonly processed including the corresponding controls.

\section{Embryo in vitro culture}

To study the effect of an altered nutrient supply on mTORC1 signalling, we cultured blastocysts of gastrulation stage 1 from healthy rabbits with L-leucine or glucose.

A twofold increase in L-leucine concentration has been observed in blastocysts from diabetic rabbits (Gürke et al. 2015). Reflecting these diabetic conditions, we cultured blastocysts with $397 \mu \mathrm{M}$ L-leucine (control) or with $800 \mu \mathrm{M}$ L-leucine (experimental group; AppliChem GmbH, Darmstadt, Germany) in $4 \mathrm{ml} \mathrm{BSM} \mathrm{II} \mathrm{medium} \mathrm{(Maurer} \mathrm{1978)} \mathrm{at} 37{ }^{\circ} \mathrm{C}$ in a water-saturated atmosphere of $5 \% \mathrm{O}_{2}, 5 \% \mathrm{CO}_{2}$ and $90 \% \mathrm{~N}_{2}$ in a water-jacketed incubator (HERAcell 150i, Thermo Fisher Scientific, Bonn, Germany) for 2 or $4 \mathrm{~h}$. To prove mTORC1 dependency, blastocysts were pre-cultured with rapamycin (125 nM/DMSO) (553210, Merck KGaA) dissolved in DMSO for $30 \mathrm{~min}$. They were subsequently cultured with 397 or $800 \mu \mathrm{M}$ L-leucine. A DMSO group was included as solvent control for rapamycin. Blastocysts were cultured in groups of three for RNA analysis. After culture, the blastocysts were stored at $-80{ }^{\circ} \mathrm{C}$ until RNA analysis.

For protein analysis, groups of 5 blastocysts were precultured for $2 \mathrm{~h}$ in $4 \mathrm{ml}$ BSM II medium (Maurer 1978) with the $397 \mu \mathrm{M} \mathrm{L}$-leucine standard concentration, followed by $397 \mu \mathrm{M}$ L-leucine (control) or $800 \mu \mathrm{M} \mathrm{L}$-leucine for $30 \mathrm{~min}$. To confirm mTORC1 dependency, blastocysts were pre-cultured with rapamycin (125 $\mathrm{nM} / \mathrm{DMSO}$ ) dissolved in DMSO for $30 \mathrm{~min}$ before L-leucine exposure. A DMSO group was included as solvent control for rapamycin.

The influence of glucose was analysed in blastocysts cultured with $10 \mathrm{mM}$ glucose (Sigma-Aldrich) in BSM II medium for $1 \mathrm{~h}$. Control embryos were cultured in medium without glucose. Rapamycin (125 nM/DMSO) was added 30 min before to the designated group. After culture, the blastocysts were stored as protein samples at $-80^{\circ} \mathrm{C}$.

\section{RNA extraction and cDNA synthesis}

mRNA isolation from single blastocysts was performed with Dynabeads Oligo $(\mathrm{dT})_{25}$ (Life Technologies). Frozen samples were thawed on ice and thereafter centrifuged for $10 \mathrm{~min}$ $13800 \mathrm{~g}$ Supernatants were discarded and tissues were re-suspended in lysis buffer according to the manufacturing protocol. Dynabeads Oligo $(\mathrm{dT})_{25}$ were added to bind beads to the $3^{\prime}$-poly(A)tail of mRNA and incubated for $10 \mathrm{~min}$. Samples were washed in magnetic particle concentrator three times. mRNA was dissolved in $11 \mu \mathrm{l}$ diethylpyrocarbonate (DEPC) water by heating to $65^{\circ} \mathrm{C}$ for $3 \mathrm{~min}$. To each sample, $10 \times$ PCR buffer, $50 \mathrm{mM} \mathrm{MgCl} 2,10 \mathrm{mM}$ dNTPs, $1 \mu \mathrm{mol}$ random primer (Roche Diagnostics), $100 \mathrm{U}$ reverse transcriptase and $8 \mathrm{U}$ RNase inhibitor (all reagents from Thermo Fisher Scientific) were added. The cDNA synthesis was performed at $25^{\circ} \mathrm{C}$ for $10 \mathrm{~min}, 42^{\circ} \mathrm{C}$ for $60 \mathrm{~min}$ and $99{ }^{\circ} \mathrm{C}$ for $4 \mathrm{~min}$. Thereafter, the samples were cooled down to $4{ }^{\circ} \mathrm{C}$. The final volume of the cDNA reaction was adjusted with water to $100 \mu \mathrm{l}$.

\section{RT-PCR}

RT-PCR amplification was carried out with $1 \mu \mathrm{l}$ cDNA from single samples in a $25-\mu$ l reaction volume containing $200 \mu \mathrm{M}$ of each dNTP, $2.5 \cup$ Taq polymerase and specific oligonucleotides for $m T O R$ and glyceraldehyde-3-phosphate dehydrogenase $(G A P D H)$ (primer listed in Table 1). RT-PCR conditions: 40 cycles including $94{ }^{\circ} \mathrm{C}$ for $45 \mathrm{~s}, 60{ }^{\circ} \mathrm{C}$ for $45 \mathrm{~s}$ and $72{ }^{\circ} \mathrm{C}$ for $60 \mathrm{~s}$. The products were separated by electrophoresis on $1.8 \%$ agarose gel stained with ethidium bromide.

\section{Cloning and sequencing of partial cDNA for rabbit LC3}

For all primers (exon spinning, listed in Table 2) RT-PCR products were purified and cloned into the pGEM-T vector (pGEM-T Vector Kit, Promega GmbH). Recombinant plasmids were sequenced using the BigDye Terminator v1.1 Cycle Sequencing Kit (Applied Biosystems/Thermo Fisher Scientific). Sequence analysis was performed with 3130xl Genetic Analyser (Applied Biosystems/Thermo Fisher Scientific) in the Core Facility: DNA-Sequencing of the Medical Faculty (Halle, Germany). Fragment identity was proven by BLASTN and BLASTX tool.A new partial LC3 (194 bp) and mTOR (249 bp) cDNA was amplified from the rabbit kidney cell line RK13 using human primers. The sequence was $95 \%$ for $m T O R$ and $97 \%$ for $L C 3$ identical with the human one at the mRNA level, as shown by BLAST tool alignment. 
Table 2 Oligonucleotides used for RT-qPCR.

\begin{tabular}{|c|c|c|c|c|}
\hline Gene & Primer sequence & Product $(b p)$ & Tm & Acc. No. \\
\hline Rabbit Beclin 1 BECN1 & $\begin{array}{l}\text { Forward: GCTGGATCAGGAGGAAGCTC } \\
\text { Reverse: TGTGCCAAACTGTCCACTGT }\end{array}$ & 190 & $60^{\circ} \mathrm{C}$ & XM_002719409.1 \\
\hline Rabbit $C C N D 1$ & $\begin{array}{l}\text { Forward: GTGGCCTCCAAGATGAAAGA } \\
\text { Reverse: TTGGAGAGGAAGTGCTCGAT }\end{array}$ & 176 & $60^{\circ} \mathrm{C}$ & DQ845180 \\
\hline Rabbit EIF4E & $\begin{array}{l}\text { Forward: CTTGGCAAGCAAACCTTCGG } \\
\text { Reverse: GGTCACTTCGTCTCTGCTGT }\end{array}$ & 213 & $60^{\circ} \mathrm{C}$ & NM_001101710.1 \\
\hline Rabbit GAPDH & $\begin{array}{l}\text { Forward: GCCGCTTCTTCTCGTGCAG } \\
\text { Reverse: ATGGATCATTGATGGCGACAACAT }\end{array}$ & 144 & $60^{\circ} \mathrm{C}$ & L23961 \\
\hline Human $L C 3$ & $\begin{array}{l}\text { Forward: GTCCCGGACCATGTCAACAT } \\
\text { Reverse: GTTTCCTGGGAGGCGTAGAC }\end{array}$ & 194 & $60^{\circ} \mathrm{C}$ & NM_032514.3 \\
\hline Rabbit $O D C 1$ & $\begin{array}{l}\text { Forward: AGTTGGTTTTGCGGATTGCC } \\
\text { Reverse: CGAAGGTCTCAGGATCGGTA }\end{array}$ & 179 & $60^{\circ} \mathrm{C}$ & XM_002722389.1 \\
\hline Rabbit $P C N A$ & $\begin{array}{l}\text { Forward: GGACACCTTGGCGCTAGTAT } \\
\text { Reverse: GGTCTCGGCATATACGTGCA }\end{array}$ & 164 & $60^{\circ} \mathrm{C}$ & XM_008256277.1 \\
\hline Rabbit $S L C 7 A B$ & $\begin{array}{l}\text { Forward: GTCCCTTGCATCTGCTAAGACT } \\
\text { Reverse: TCCAAAAAGTAAGGCATCCACT }\end{array}$ & 234 & $60^{\circ} \mathrm{C}$ & NM_001082682.1 \\
\hline Human $m T O R$ & $\begin{array}{l}\text { Forward: AGTGGACCAGTGGAAACAGG } \\
\text { Reverse: CAGTTCAGACCAGCAGGACA }\end{array}$ & 249 & $60^{\circ} \mathrm{C}$ & NM_004958.3 \\
\hline
\end{tabular}

\section{Real-time $R T-q P C R$}

Relative mRNA amounts of the investigated genes were determined by quantitative real-time analysis (RT-qPCR) with SYBR Green detection. The MESA Blue qPCR MasterMix Plus for SYBR Assay (Eurogentec, Köln, Germany) was used to measure duplicates of each cDNA sample together with no template control for each primer set. According to the manufacturing protocol, $3 \mu \mathrm{l}$ cDNA per sample was used. The thermocycling parameters for StepOnePlus Real-Time PCR Systems (Applied Biosystems) were as follows: activation of polymerase for $5 \mathrm{~min}$ at $95^{\circ} \mathrm{C}, 40$ cycles of denaturation (10 s $95^{\circ} \mathrm{C}$ ), primer binding for $15 \mathrm{~s}$ at $60^{\circ} \mathrm{C}$ and elongation for $20 \mathrm{~s}$ at $72{ }^{\circ} \mathrm{C}$. At the end of the amplification, a melt curve in the range of $95-55{ }^{\circ} \mathrm{C}$ with $0.5^{\circ} \mathrm{C}$ intervals was plotted. In each real-time $\mathrm{RT}-\mathrm{qPCR}$, a calibration curve was included from serial dilutions in a range from $10^{8}$ to $10^{3}$ copies of primerspecific DNA plasmid standards. PCR efficiencies were estimated by means of the standard curve. The primer sequences used in this study are documented in Table 1. The reference gene GAPDH was quantified as endogenous control. $G A P D H$ had been shown to be unaffected by alloxan treatment in a recent study (Thieme et al. 2012). For data analysis, the StepOne Software v2.0 (Applied Biosystems) was used. Total molecule numbers of each sample were determined by linear regression of the plasmid standard. The target gene expression was normalised to that of GAPDH in each sample. Results were calculated as amounts of target RNA in molecules per molecules GAPDH RNA and expressed as relative amounts in percentage or fold change of control samples.

\section{Protein preparation and immunoblotting}

Protein isolation was performed as described before (Gürke et al. 2015) with $25 \mu \mathrm{g}$ protein. The nylon membranes were stained with Ponceau S after blotting. Molecular weights were determined by comparison with PageRuler pre-stained molecular weight markers (Fermentas, St Leon-Rot, Germany). The immunoreactive signals were visualised by enhanced chemiluminescence detection (Millipore, Schwalbach,
Germany) and quantified by Fusion Fx7 Imaging System (Peqlab, Erlangen, Germany). The following antibodies were used: anti-phospho-mTOR (Ser2448) (rabbit Ab, 1:500, \#2971), anti-mTOR (rabbit Ab, 1:500, \#2972), anti-phosphop70S6K1 (Thr389) (mouse Ab, 1:1000, \#9206) (all NEB, Frankfurt, Germany), anti-S6K1 (mouse Ab, 1:5000, WH0006198M1) (Sigma-Aldrich), anti-phospho-4E-BP1 (Thr37/46) (mouse Ab, 1:1000, \#9459), anti-4E-BP1 (mouse Ab, 1:1000, \#9452), anti-p62 (rabbit Ab, 1:500, \#8025) (all Cell Signalling Technology), $\beta$-actin (mouse Ab, 1:20000, A-5441; Sigma-Aldrich), anti-rabbit IgG conjugated to HRP (1:6000, DAKO Cytomation, Hamburg, Germany) and antimouse IgG conjugated to HRP (1:10000, Dianova, Hamburg, Germany). Protein amounts were evaluated by re-blotting with $\beta$-actin antibody after stripping the membranes. Protein amounts were calculated as ratio of band intensities (p62 vs $\beta$-actin) in the same blot. Phosphorylation amounts were calculated as ratio of band intensities ( $p$-mTOR or p-p70S6K or $\mathrm{p}-4 \mathrm{E}-\mathrm{BP} 1 \mathrm{vs} \mathrm{mTOR}$ or S6K or 4E-BP1) in the same blot.

\section{Protein synthesis}

For protein synthesis analysis, the Click-iT HPG Alexa Fluor 488 Protein Synthesis Assay Kit (C10428, Life Technologies GmbH) was used. After flushing, blastocysts of gastrulation stage 2 from diabetic and healthy rabbits were cultured, according to the manufacturers manual, with 1:1000 Component A (methionine analogue L-homopropargylglycine (HPG)) in methionine-free medium for $1 \mathrm{~h}$. After washing with $0.05 \%$ PVA/PBS (w/v), fixation in $4 \%$ paraformaldehyde (PFA; w/v) and washing repeatedly, the blastocysts were incubated in PBS/PVA containing $1 \%(\mathrm{w} / \mathrm{v})$ BSA and $0.1 \%(\mathrm{v} / \mathrm{v})$ Triton X-100 for $30 \mathrm{~min}$. The blastocysts were washed and incubated with reaction cocktail, according to the manufacturer's manual, for $45 \mathrm{~min}$ in the dark. The nuclei were counterstained for $30 \mathrm{~min}$ with Nuclear Mask Blue Stain (1:2000 in 0.05\% PVA/PBS) from the kit. Blastocysts were embedded on StarFrost slides (Knittel, Braunschweig, Germany) using Mowiol 4-88 reagent (\#475904, Merck KGaA). Trophoblast cells were examined with 


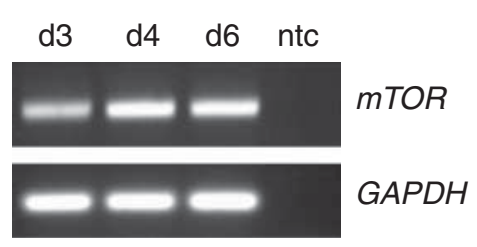

Figure 1 Expression of mTOR in rabbit embryos. Expression of $m T O R$ was determined in preimplantation rabbit embryos at days 3 (d3; morulae), 4 (d4; early blastocysts) and 6 (d6; expanded blastocysts) p.c. by RT-PCR. Transcripts of $m T O R$ were present in all investigated stages. Internal control was the expression of GAPDH in all probes. A probe without cDNA was used as negative control (ntc, non-template control).

fluorescence microscopy (BZ 8000, Keyence, Neu-Isenburg, Germany) and Z-stack setting. From each individual samples, two data sets of different trophoblast positions with Z-stack of 12-15 pictures were documented. All steps were performed within the same experiment and examined microscopically during the same session, using identical microscope and camera settings. Intensity analysis of green fluorescence signal was performed with the Image Analysis Software Volocity 3D (Perkin Elmer, Rodgau, Germany).

\section{Staining of lysosomes}

Blastocysts were cultured with 100 nM LysoTracker Deep Red (L12492, Life Technologies $\mathrm{GmbH}$ ) in standard culture media for $2 \mathrm{~h}$. Thereafter, embryos were washed in 0.05\% PVA/PBS $(\mathrm{w} / \mathrm{v})$, fixed in 4\% PFA ( $\mathrm{w} / \mathrm{v})$ and repeatedly washed in PBS.

After washing, the nuclei were counterstained for $30 \mathrm{~min}$ with Hoechst $(1: 200$ in $0.05 \%$ PVA/PBS). Blastocysts were embedded on StarFrost slides (Knittel) using Mowiol 4-88 reagent (\#475904, Merck KGaA). All image acquisition was performed on a confocal TCS SP5 LSM microscope (Leica, Biberach, Germany) using a $63 \times$ objective with oil (Plan Apo $63 \times$; Leica) and standardised settings for sequential imaging. Images were acquired by accumulation of z-series from trophoblast cells. From each individual samples, three data sets of different trophoblast positions with Z-stack were documented. All steps were performed using identical microscope and camera settings. Intensity analysis of redstained vesicles and counting of lysosomes in trophoblast cells were performed with the Image Analysis Software Volocity 3D (Perkin Elmer). Single cells were cropped and lysosomal vesicles (red fluorescence) were counted in a size range from 0.01 to $8 \mu \mathrm{m}^{3}$. Intensity of red fluorescence was measured from selected lysosomal vesicles as total vesicle volume per cell by Volocity 3D software algorithm.

\section{Statistical analysis}

Data are expressed as mean \pm S.E.M. Levels of significance between groups were calculated using Student's $t$-test after proving normal distribution. Multiple comparisons were made by factorial variance analysis (ANOVA) adjusted according to Bonferroni (Sigma Plot v. 12.0). Statistical significances are indicated as follows: ${ }^{*} P<0.05,{ }^{* *} P<0.01$ and ${ }^{* * *} P<0.001$. The number of experimental replicates is marked with $N$. The number of analysed blastocysts per group is indicated by $n$.

\section{Results \\ Expression of $m T O R$ in rabbit preimplantation embryos}

Figure 1 documents the ontogenetic pattern of $m T O R$ expression in morulae (day 3), early blastocysts (day 4) and expanded blastocysts (day 6). Transcripts of $m T O R$ were present in all investigated stages.

\section{Phosphorylation of mTORC1, S6K1 and 4E-BP1 in embryoblast and trophoblast of rabbit blastocysts}

Phosphorylation state of mTORC1, S6K1 and 4E-BP1 was analysed in the embryoblast and trophoblast of gastrulation stage 2 blastocysts by western blot assays (Fig. 2A). Relative phosphorylation of mTORC1, S6K1 and 4E-BP1 was significantly higher in trophoblast cells than in embryoblast cells (Fig. 2B). The protein amounts of mTORC1 and S6K1 were equal in both cell lineages,

A

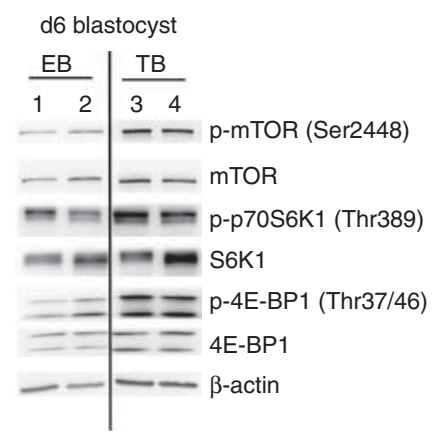

$B$

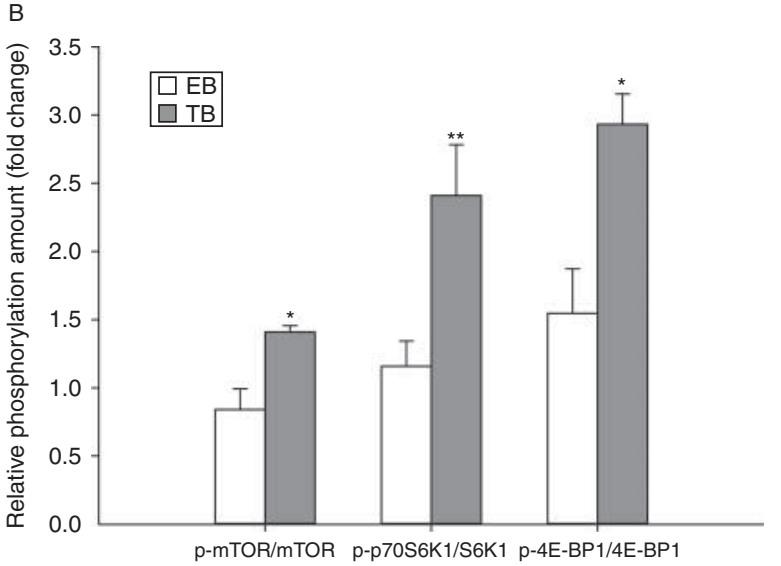

Figure 2 Phosphorylation of mTOR, S6K1 and 4E-BP1 in the embryoblast (EB) and trophoblast (TB) of rabbit blastocysts. The protein and relative phosphorylation amounts of mTOR, S6K1 and 4E-BP1 were detected by western blot. In (A), a representative western blot of two pooled protein samples ( $n \geq 5$ per sample) from embryoblast (lanes 1,2) and trophoblast (lanes 3, 4) cells is shown. (B) The amount of phosphorylated protein was related to the non-phosphorylated protein. The amounts of phosphorylated protein of trophoblast samples were calculated relative to the embryoblast samples (set 1). mTOR, S6K1 and 4E-BP1 showed significantly higher phosphorylation amounts in trophoblast cells than in embryoblast cells $(N=3 ; n \geq 15$; $\left.{ }^{*} P<0.05 ;{ }^{* *} P<0.005\right)$. 

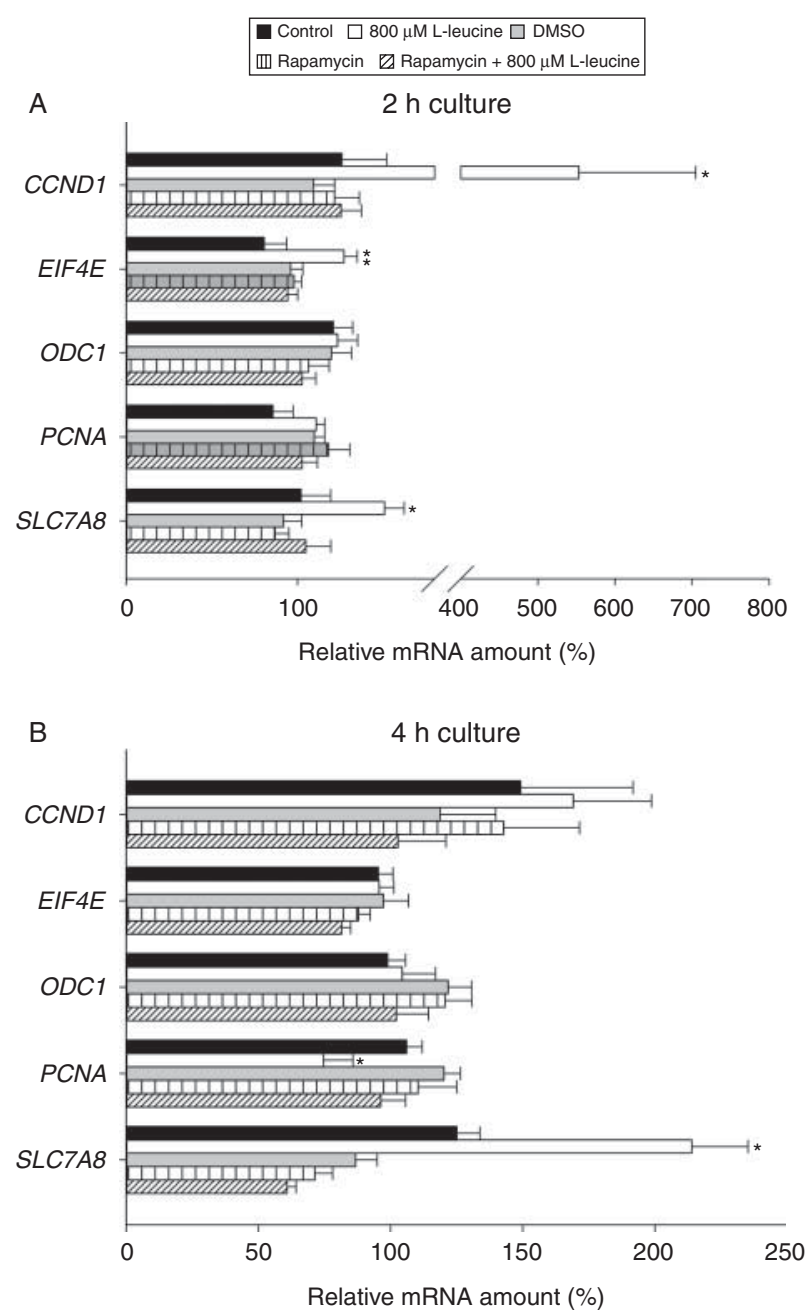

Figure 3 Expression of $\mathrm{mTORC} 1$ downstream targets in rabbit blastocysts cultured in vitro with $397 \mu \mathrm{M} \mathrm{L-leucine} \mathrm{(control)} \mathrm{or} 800 \mu \mathrm{M}$ L-leucine. Blastocysts were cultured with $397 \mu \mathrm{M} \mathrm{L-leucine} \mathrm{(control)} \mathrm{or}$ $800 \mu \mathrm{M}$ L-leucine for $2 \mathrm{~h}$ (A) or $4 \mathrm{~h}$ (B). To analyse mTORC1dependend expression of CCND1, EIF4E, ODC1, PCNA and SLC7A8 blastocysts were pre-incubated with the $\mathrm{mTORC} 1$ inhibitor rapamycin (125 nM). mRNA amounts were quantified by RT-qPCR in single blastocysts. The control group, i.e. blastocysts cultured with $397 \mu \mathrm{M}$ L-leucine, was set $100 \%\left(N=3 ; n \geq 9 ;{ }^{*} P<0.05 ;{ }^{* *} P<0.01\right.$ significantly different compared to control).

whereas the amount of $4 \mathrm{E}-\mathrm{BP} 1$ protein was lower in the trophoblast than in the embryoblast. In trophoblast cells, the protein amount of $4 \mathrm{E}-\mathrm{BP} 1$ was approximately half of the amount as in embryoblast cells (embryoblast: $87.7 \pm 6.2 \%$; trophoblast: $59.0 \pm 1.7 \% ; P=0.004$ ).

\section{Activation of mTORC1 downstream targets by L-leucine in rabbit blastocysts in vitro}

To further analyse signalling effects of the increased L-leucine concentration observed in vivo (Gürke et al. 2015), rabbit blastocysts were cultured in vitro with $800 \mu \mathrm{M}$ L-leucine for 2 or $4 \mathrm{~h}$, i.e. in a L-leucine concentration twice as high as in the control group reflecting the diabetic condition.

The mRNA amounts of potential mTORC1 downstream targets were quantified by RT-qPCR. Culture for $2 \mathrm{~h}$ with L-leucine increased the embryonic mRNA amounts of CCND1, EIF4E and SLC7A8 compared to the control group (Fig. 3A). A simultaneous incubation with rapamycin blocked this effect, demonstrating that the increase in gene expression was mTORC1-dependent. After $4 \mathrm{~h}$ stimulation, no further increase in mRNA amounts of CCND1 and EIF4E by L-leucine was measured, whereas SLC7A8 mRNA amount continued to increase (Fig. 3B). The mRNA amount of proliferating cell nuclear antigen (PCNA) was decreased and rapamycin inhibited this effect again. The transcription of ornithine decarboxylase 1 (ODC1) was not affected by L-leucine after 2 or $4 \mathrm{~h}$.

\section{Activation of the mTORC1 signalling by L-leucine in rabbit blastocysts in vitro}

L-leucine is a potent activator of the mTORC1 signalling pathway. mTORC1 and its downstream target S6K1 was analysed by a western blot based phosphorylation assay. The phosphorylation amounts of mTORC1 and S6K1 were significantly higher in $800 \mu \mathrm{M}$ L-leucine supplemented embryos compared to controls with $397 \mu \mathrm{M}$ L-leucine after $30 \mathrm{~min}$ (Fig. 4A and B). Rapamycin inhibited the rise in mTORC1 phosphorylation, and for S6K1, no phosphorylation was detectable at all (Fig. 4A and B).

\section{Activation of the mTORC1 signalling by glucose in rabbit blastocysts in vitro}

To further analyse the effects of high glucose concentrations observed in uterine fluid from diabetic rabbits (Ramin et al. 2010), blastocysts from healthy rabbits were cultured with high $(10 \mathrm{mM})$ glucose concentration and without glucose (controls). The $10 \mathrm{mM}$ glucose concentration induced mTORC1 and S6K1 phosphorylation. An inhibition by rapamycin reduced $\mathrm{mTOR}$ phosphorylation by half and S6K1 completely (Fig. 4C and D).

\section{mTORC1 signalling in blastocysts from diabetic rabbits}

Phosphorylation states of mTORC1, S6K1 and 4E-BP1 were measured in the embryoblast and trophoblast of gastrulation stage 2 blastocysts from diabetic rabbits by western blot assays (Fig. 5). Relative phosphorylation of mTORC1, S6K1 and 4E-BP1 was significantly higher in trophoblast cells than in embryoblast cells (Fig. 5B). The protein amounts of $\mathrm{mTORC} 1, \mathrm{~S} 6 \mathrm{~K} 1$ and $4 \mathrm{E}-\mathrm{BP} 1$ were significantly higher in trophoblast than in the embryoblast. In trophoblast cells, the protein amount of S6K1 was approximately twofold higher compared to 

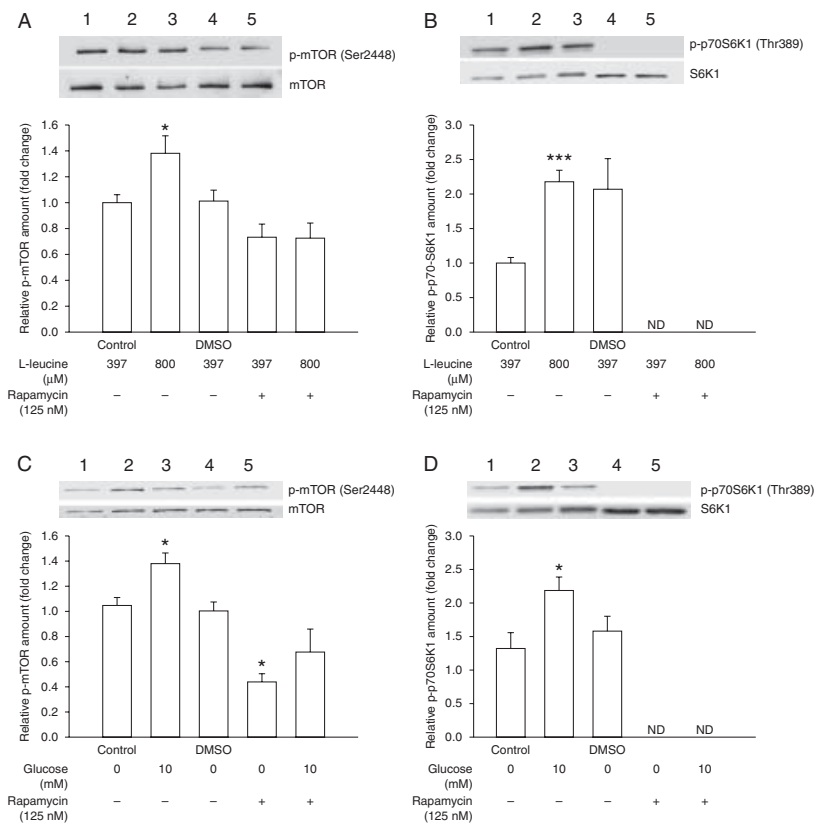

Figure 4 Activation of mTORC1 signalling by L-leucine and glucose in rabbit blastocysts. The relative phosphorylation amounts of mTORC1 and S6K1 were detected by western blot in in vitro cultured blastocysts. Blastocysts were cultured for $30 \mathrm{~min}$ with 397 (control) or $800 \mu \mathrm{M}$ L-leucine. Rapamycin (125 nM/DMSO) was used as inhibitor of mTORC1 activation. Vehicle control of rapamycin was performed with DMSO. The amount of phosphorylated protein was related to the nonphosphorylated protein and calculated relative to the control group cultured with $397 \mu \mathrm{M} \mathrm{L-leucine} \mathrm{(set} \mathrm{1).} \mathrm{Phosphorylation} \mathrm{of} \mathrm{mTORC1}$ (A) and S6K1 (B) was higher after $800 \mu \mathrm{M} \mathrm{L-leucine} \mathrm{stimulus.}$

Rapamycin treatment inhibited this effect. A representative western blot is shown with one pooled sample for each treatment $(n=5$ per sample; lane 1 - control sample with $397 \mu \mathrm{M}$ L-leucine; 2 - $800 \mu \mathrm{M}$ L-leucine; 3 - DMSO; 4 - $397 \mu \mathrm{M}$ L-leucine and $125 \mathrm{nM}$ rapamycin; 5 - $800 \mu \mathrm{M}$ L-leucine and $125 \mathrm{nM}$ rapamycin). Blastocysts were cultured without (control) and with $10 \mathrm{mM}$ glucose for $60 \mathrm{~min}$. The amount of phosphorylated protein was related to the non-phosphorylated protein and calculated relative to the control group cultured without glucose (set 1). Blastocysts in $10 \mathrm{mM}$ glucose showed a higher phosphorylation of mTORC1 (C) and S6K1 (D) compared to blastocysts without glucose. Rapamycin treatment inhibited this effect. A representative western blot is given as one pooled protein sample for each treatment $(n=5$ per sample; 1 - control $0 \mathrm{mM}$ glucose; 2 - $10 \mathrm{mM}$ glucose; 3 - DMSO $4-0 \mathrm{mM}$ glucose and $125 \mathrm{nM}$ rapamycin; $5-10 \mathrm{mM}$ glucose and $125 \mathrm{nM}$ rapamycin $)\left(N=3 ; n=15 ; * P<0.05 ;{ }^{* * *} P<0.001\right)$.

embryoblast cells (embryoblast: $85.2 \pm 12.4 \%$; trophoblast: $190.0 \pm 32.2 \% ; P=0.039$ ). Protein amounts of mTOR and 4E-BP1 were fourfold higher in trophoblast cells as in embryoblast cells (mTOR $=$ embryoblast: $72.65 \pm 25.1 \%$; trophoblast: $493.5 \pm 122.1 \%$; $P=0.049$; 4E-BP1 = embryoblast: $83.6 \pm 10.4 \%$; trophoblast: 412.1 $\pm 126.0 \% ; P=0.030$ ).

Our in vitro data demonstrated alterations in embryonic mTORC1 signalling and mTORC1-dependent gene expression. As proof of concept the mTORC1 signalling in blastocysts from diabetic rabbits was studied next.

The absolute protein amounts of all investigated proteins were not changed by maternal diabetes. In blastocysts from diabetic rabbits, S6K1 phosphorylation level was $\sim 1.5$-fold higher than in healthy controls (Fig. 6). Phosphorylation of embryonic 4E-BP1 was not affected (Fig. 6).

Expressions of CCND1 and EIF4E were significantly increased in blastocysts from diabetic rabbits compared to healthy controls (Table 3 ), while PCNA expression was decreased. The mRNA amount of embryonic ODC1 was not affected by maternal diabetes (Table 3 ).

\section{Protein synthesis in blastocysts from diabetic rabbits}

Enhanced mTORC1 signalling is expected to stimulate protein synthesis. Using Alexa Fluor 488 staining and the Click-iT HPG reaction kit in blastocysts from diabetic and healthy rabbits, we found a twofold higher green fluorescence signal in trophoblast cells of blastocysts from diabetic rabbits, indicating enhanced protein synthesis, than in healthy controls (Fig. 7).

A d6 blastocyst from diabetic rabbits
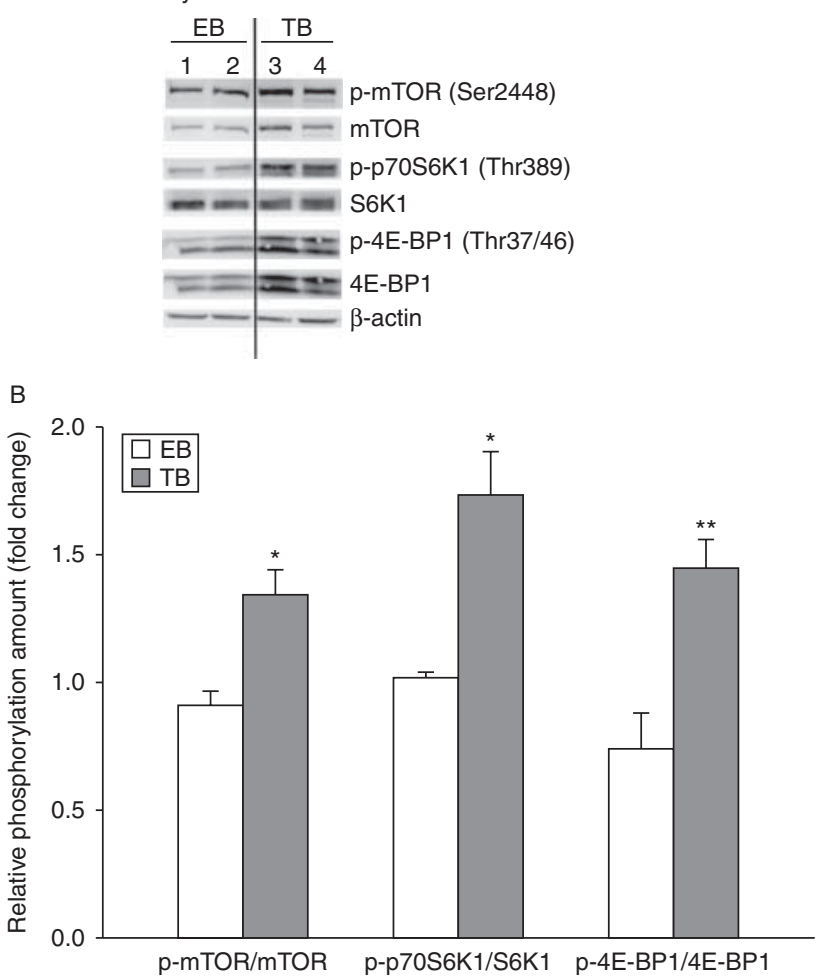

Figure 5 Phosphorylation of $m T O R, S 6 K 1$ and 4E-BP1 in the embryoblast (EB) and trophoblast (TB) of rabbit blastocysts from diabetic rabbits. The protein and relative phosphorylation amounts of $\mathrm{mTOR}, \mathrm{S} 6 \mathrm{~K} 1$ and 4E-BP1 were detected by western blot. In (A), a representative western blot of two pooled protein samples $(n \geq 3$ per sample) from embryoblast (lanes 1,2) and trophoblast (lanes 3, 4) cells is shown. (B) The amount of phosphorylated protein was related to the non-phosphorylated protein. The amount of phosphorylated protein of trophoblast samples was calculated relative to the embryoblast samples (set 1). mTOR, S6K1 and 4E-BP1 showed significantly higher phosphorylation amounts in trophoblast cells than in embryoblast cells of blastocysts from diabetic rabbits $(N=3 ; n \geq 10 ; * P<0.05$; $* * P<0.005)$. 
A
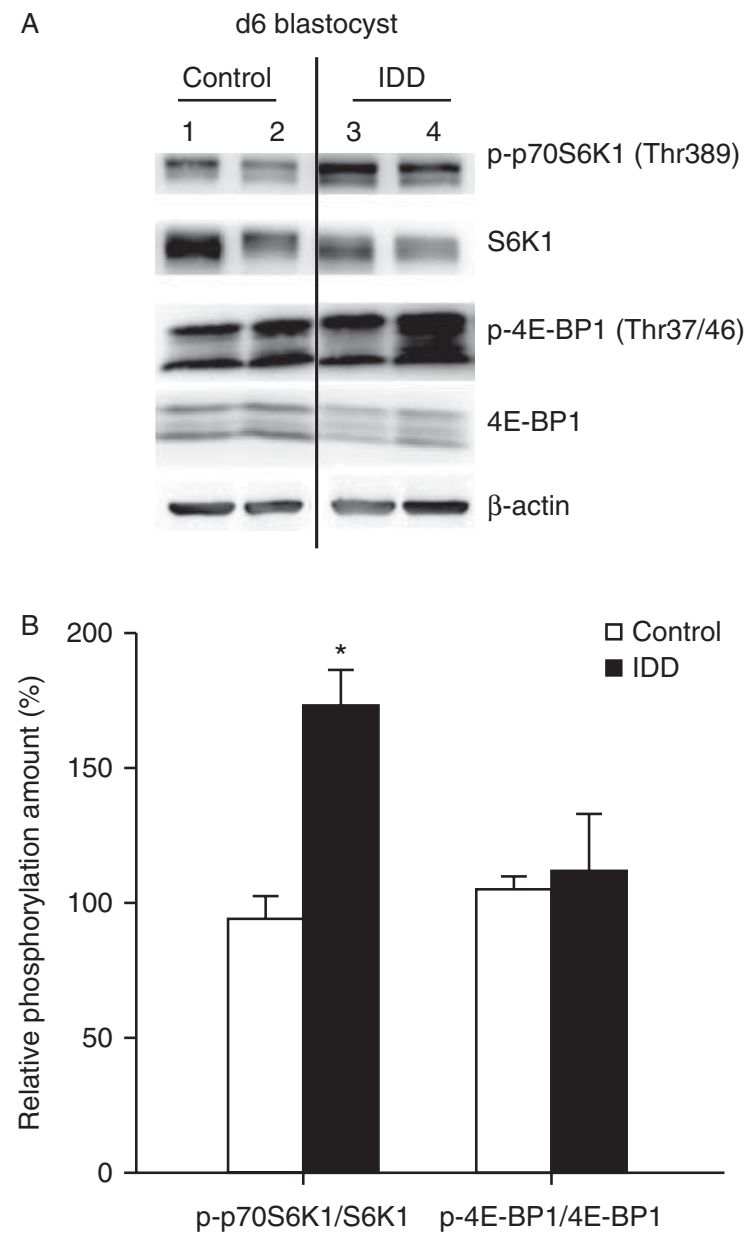

Figure 6 Phosphorylation of S6K1 and 4E-BP1 in blastocysts from diabetic (IDD) rabbits. The relative phosphorylation amounts of S6K1 and 4E-BP1 were quantified by western blotting in blastocysts of gastrulation stage 2 from healthy (control) and diabetic (IDD) rabbits. In (A), a representative western blot of two pooled samples $(n \geq 7$ per sample) from blastocysts of healthy (control; lanes 1,2 ) and diabetic (IDD; lanes 3, 4) rabbits is shown. In (B), the amount of phosphorylated protein was related to the non-phosphorylated protein and calculated relative to controls (set $100 \%)\left(N=4 ; n=30 ;{ }^{*} P<0.05\right)$.

\section{Autophagy in blastocysts from diabetic rabbits}

The protein amount of the autophagy marker nucleoporin p62 was reduced by half in blastocysts from diabetic rabbits in comparison to the controls (Fig. 8A). However, the relative mRNA amounts of other autophagy markers such as BECN1 and LC3 were similar in both groups (Fig. 8B).

\section{Lysosomes detection in diabetic rabbits}

To further analyse autophagic activity of blastocysts, the number and volume of lysosomes were determined in blastocysts from diabetic and healthy rabbits. Therefore, the blastocysts were stained with lysosomal dye LysoTracker Deep Red (Fig. 9A).
Blastocysts from healthy rabbits revealed lysosomes in the range $61.54 \pm 2.56$ lysosomes per cell. In mammalian cells, the amount of lysosomes varies from 50 to 1000 per cell (Meyer 2002). Blastocysts from diabetic rabbits displayed decreased amount of lysosomal vesicles (with $34.54 \pm 2.89$ ) in trophoblast cells (Fig. 9B). Further, within these cells, the total volume of labelled lysosomal vesicles per cell was reduced (Fig. 9C).

\section{Discussion}

Previous reports have demonstrated the vital requirement for mTORC1 signalling in early embryonic development (Gangloff et al. 2004, Guertin et al. 2006). The activation by amino acids of mTORC 1 is an important aspect of blastocyst development and necessary for the invasive behaviour of the trophectoderm (Martin \& Sutherland 2001, Martin et al. 2003, González et al. 2011). Here we demonstrate that mTORC1 signalling is affected by L-leucine in rabbit blastocysts. Both changes, high leucine concentration in vitro and in utero in maternal diabetes, interact with embryonic mTORC1 signalling. Higher plasma levels of L-leucine in diabetes have been reported in humans (Felig et al. 1970) and in a previously published study in the rabbit (Gürke et al. 2015). It is therefore highly likely that the increased maternal L-leucine contributes to mTORC1 activation observed in blastocysts during a diabetic pregnancy.

In the current study, we have tried to discriminate and further characterise L-leucine and glucose stimulation of mTORC1 signalling. High L-leucine and glucose concentrations are typical for a diabetic pregnancy.

That L-leucine alone is able to activate signalling via mTORC1 was shown in rat tissues by Lynch and colleagues (Lynch et al. 2002). In the ovine conceptus cultured with selected nutrients, leucine showed, besides arginine and glucose, a positive effect of phosphorylation of mTORC1 and its downstream target S6K1 (Kim et al. 2011b). A dose-dependent induction of mTORC1 signalling by glucose had already been shown before in mammals (Inoki et al. 2003). In addition, high glucose concentrations in vitro led to a rapamycinsensitive activation of mTORC1 signalling in rabbit blastocysts. A previous study had shown a threefold

Table 3 Expression of downstream targets of mTORC1 in blastocysts from diabetic rabbits (IDD).

\begin{tabular}{lccc}
\hline & Control & IDD & P value \\
\hline CCND1 & $92.5 \pm 8.6$ & $129.8 \pm 13.2$ & 0.036 \\
EIF4E & $89.8 \pm 11.4$ & $125.7 \pm 11.6$ & 0.047 \\
ODC1 & $127.7 \pm 14.0$ & $104.3 \pm 14.1$ & - \\
PCNA & $97.3 \pm 6.8$ & $71.2 \pm 6.4$ & 0.02 \\
\hline
\end{tabular}

Relative mRNA amounts are given as percentage of transcript amounts of blastocysts from healthy rabbits (control) (mean \pm s.E.M.; $N=3$; $n=10)$. 
Trophoblast of $\mathrm{d} 6$ blastocyst
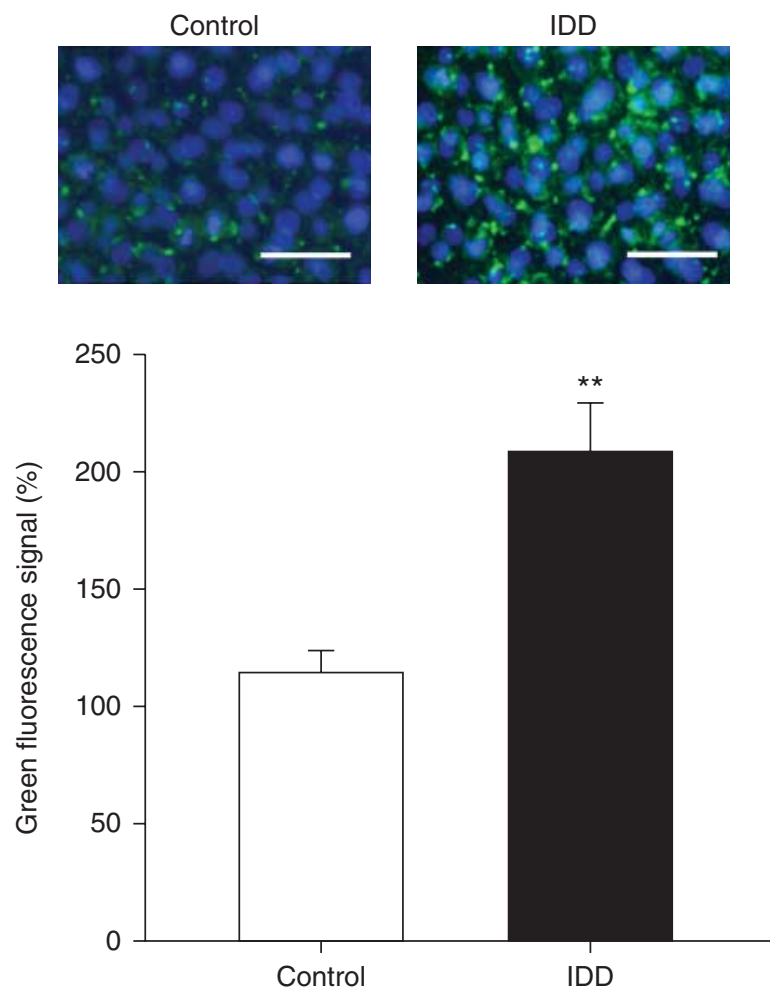

Figure 7 Protein synthesis in blastocysts from diabetic (IDD) rabbits. The protein synthesis was visualised by Click-iTHPG Alexa Fluor Protein Synthesis Assay in rabbit blastocysts. The green fluorescence signal was measured in trophoblast cells of six individual rabbit blastocysts from three independent experiments. The green fluorescence signal from blastocysts of healthy rabbits (control) is set $100 \%$. In trophoblast cells of blastocysts from diabetic rabbits (IDD), a twofold higher fluorescence signal was measured (scale bar corresponds to $50 \mu \mathrm{m} ; N=3 ; n=6 ;{ }^{*} P<0.01$ ).

increase of glucose in uterine fluid during diabetes (Ramin et al. 2010). Besides leucine and glucose, insulin signalling activates a series of phosphorylation events leading to the activation of mTORC1 pathway (reviewed by Hay (2005)). But mTORC1 can be activated by nutrients independent of insulin and other growth factors (Kwon et al. 2004). In our in vitro experiments, rabbit blastocysts revealed an increase in mTORC1 signalling just by amino acid supply and without insulin. This situation is comparable to the in vivo situation of a diabetic pregnancy as demonstrated before (Gürke et al. 2015), where blastocysts having no excess to insulin activate mTOR signalling and adapt to metabolic changes (Ramin et al. 2010). We show that glucose and L-leucine are able to activate mTORC1 signalling each for itself in vitro. In the case of a diabetic pregnancy, glucose and L-leucine are increased in the uterine environment, correlating with enhanced embryonic mTORC1 and S6K1 activation and altered gene expression of mTORC1-dependent genes. Expression of proliferation marker PCNA was decreased
A d6 blastocyst
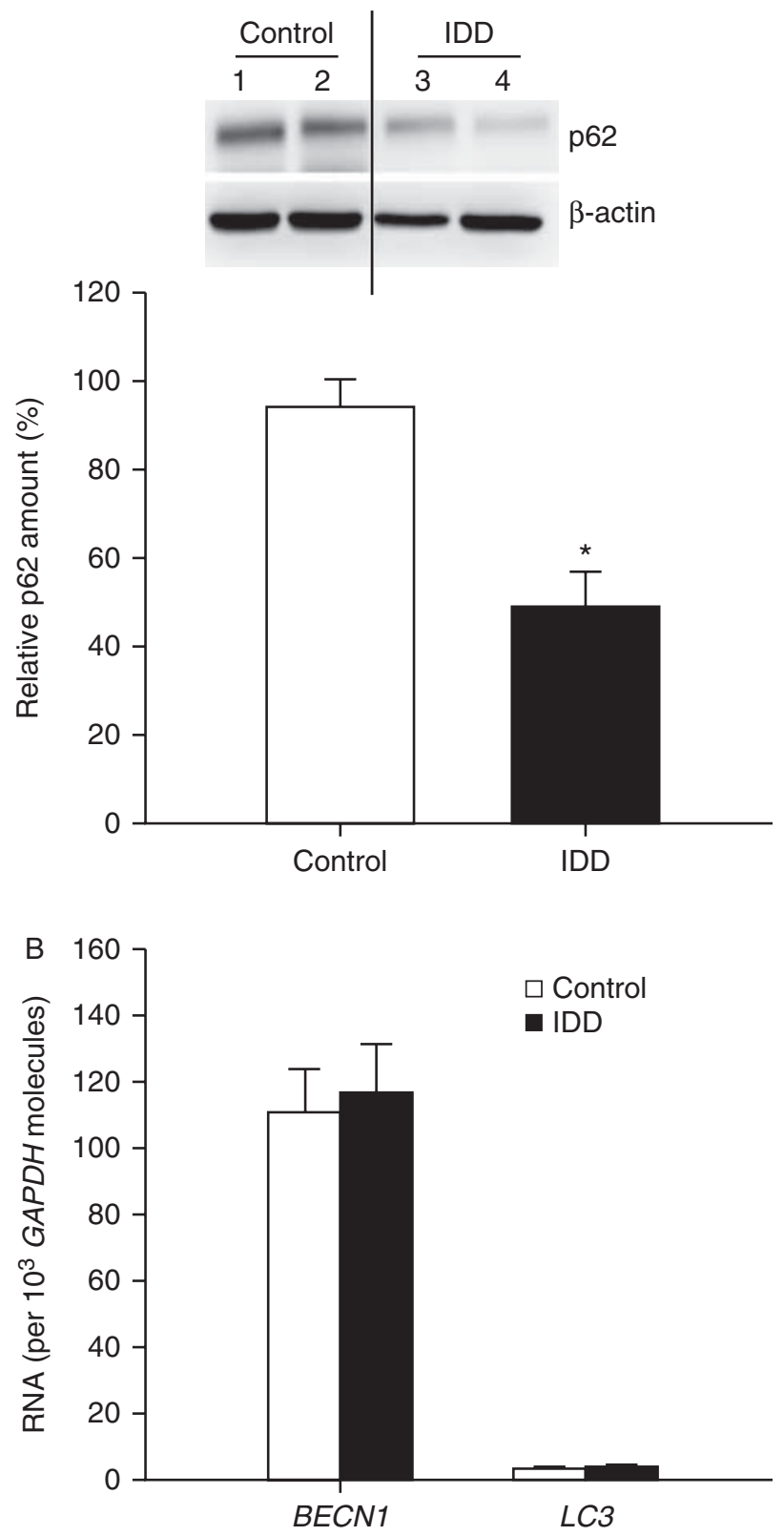

Figure 8 Autophagy in blastocysts from diabetic (IDD) rabbits. (A) The relative p62 protein amount was quantified by western blot in blastocysts of gastrulation stage 2 from healthy (control) and diabetic (IDD) rabbits. A representative western blot of two pooled samples ( $n \geq 7$ per sample) from blastocysts of healthy (control; lanes 1,2$)$ and diabetic (IDD; lanes 3,4$)$ rabbits is given. $\beta$-actin was used as loading control. The amount of p62 protein was related to $\beta$-actin protein and calculated relative to healthy blastocysts (set $100 \%$ ). The protein amount of p62 was decreased by half in blastocysts from diabetic rabbits compared to healthy controls $\left(N=4 ; n=30 ;{ }^{*} P<0.05\right)$.

(B) The mRNA amounts of BECN1 and $L C 3$ were quantified by RT-qPCR in blastocysts of gastrulation stage 2 from healthy and diabetic rabbits. $B E C N 1$ and $L C 3 \mathrm{mRNA}$ amounts were unaltered in blastocysts by maternal diabetes $(N=3 ; n=9 ; * P<0.05)$. 
A

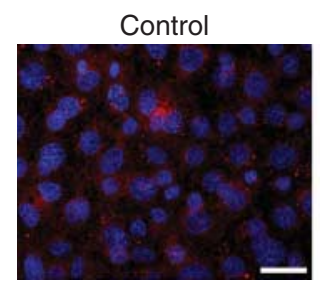

B

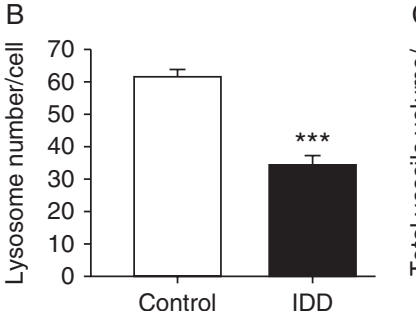

Trophoblast of d6 blastocyst

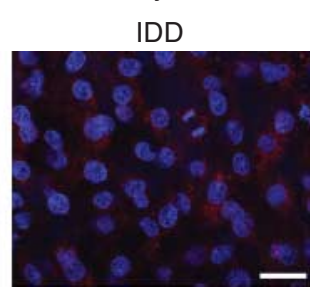

C

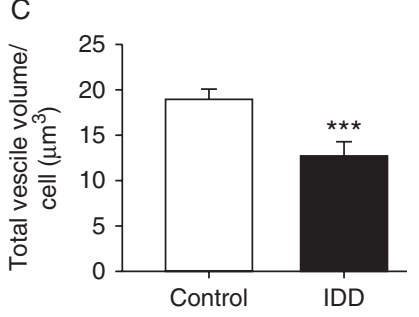

Figure 9 Lysosomal staining (A) and determination of vesicle number (B) and volume (C) in rabbit blastocysts. Lysosomes were stained with LysoTracker Deep Red in blastocysts from healthy (control) and diabetic (IDD) rabbits. Nuclei were counterstained with Hoechst (blue colour). A representative microscopically acquisition is given (A). The lysosome number $(B)$ and total vesicle volume $(C)$ per cell were estimated in trophoblast cells by counting red vesicles in a size range from 0.01 to $8 \mu \mathrm{m}^{3}$ and red vesicle volume by the Volocity 3D software algorithm. Trophoblast cells of blastocysts from diabetic rabbits revealed significantly lower lysosome numbers and total vesicle volume (scale bar corresponds to $31 \mu \mathrm{m} ; N=3 ; n=10 ;{ }^{* * *} P<0.001$ ).

with high L-leucine in cultured blastocysts in vitro and in blastocysts from diabetic. This result coincides with an increase in apoptotic cells in embryoblasts and a developmental delay in blastocysts grown in diabetic rabbits (Ramin et al. 2010). Transcription of genes involved in cell cycle and translation initiation (CCND1 and EIF4E) as further mTORC1 targets were clearly increased, as they were in blastocysts from diabetic. Consequently, enhanced mTORC1 signalling generated by L-leucine exposure results in an increased protein synthesis. We found that the higher protein synthesis occurred in trophoblast cells. It has been proposed that the metabolism of embryos is quiet rather than active and that this metabolic status is important for embryonic viability (Leese 2002). Higher embryonic protein synthesis would disturb the metabolic 'quietness' of the embryo and may contribute to diabetic embryopathies.

In addition, autophagy seems to be reduced in blastocysts from diabetic rabbits, as suggested by our p62 and lysosome results. Autophagy is necessary for intracellular quality control. In vitro and in vivo studies in preimplantation murine embryos showed that cells respond to a hyperglycaemic environment with an increase in autophagy (Adastra et al. 2011). Any alteration in the environment may lead to a dysregulation of the autophagic system potentially resulting in cell death. Autophagy may also support cell death dependent

on cellular and environmental coherence through excessive degradation of intracellular components (Levine \& Yuan 2005). Both the decrease in PCNA expression and the dysregulation of autophagy coincide with more apoptotic cells in blastocysts of diabetic rabbits as well as their developmental delay at day 6 p.c. (Ramin et al. 2010). But, a second aspect merits attention. There is evidence that p62 represses adiposity (Rodriguez et al. 2006). A deficiency in p62 leads to enhanced adipogenesis in vitro and in vivo (Rodriguez et al. 2006, Lee et al. 2010). Furthermore, activated mTORC1 regulates lipid synthesis positively, through activation of sterol regulatory element binding protein 1 (SREBP1) and peroxisome proliferator-activated receptor gamma (PPARG) (Kim \& Chen 2004, Porstmann et al. 2008). An inhibition of mTORC1 in adipose tissue leads to a lean phenotype with resistance to high-fat dietinduced obesity (Polak et al. 2008). A loss of the mTORC1 downstream target S6K1 results in an obesity-resistant phenotype (Um et al. 2004). Thus, combined results lead to the suggestion that p62 and S6K1 have antagonistic functions in pathways controlling adipogenesis and obesity. The massive lipid accumulation in blastocysts developed under diabetic conditions with a simultaneously increased ratio of nuclear vs cytoplasmatic SREBP1 shown in a previous study (Schindler et al. 2013) could therefore arise from higher mTORC1 signalling and decreased p62 levels in these blastocysts.

Functional changes in the prenatal metabolism may promote the development of obesity (Ashwell et al. 1987, Dulloo \& Girardier 1993). Intrauterine leucine availability is one of the key factors that may affect the predisposition to diseases in adulthood caused by maternal low-protein diet, obesity, type 2 diabetes mellitus and for cardiovascular diseases (Langley et al. 1994, Langley-Evans et al. 1996, Heywood et al. 2004, Eckert et al. 2012). We show that an altered maternal nutritional environment is associated with increased embryonic mTORC1 signalling. Higher activation of mTORC1 signalling may lead to enhanced embryonic protein synthesis and simultaneously reduced autophagy, and may contribute to mis-programming of the metabolic pathways with long-lasting effects on pre and postnatal development.

\section{Declaration of interest}

The authors declare that there is no conflict of interest that could be perceived as prejudicing the impartiality of the research reported.

\section{Funding}

This work was supported by EU FP7 EpiHealth (N 278418), EpiHealthNet, Cost Action EpiConcept FA1201 and SALAAM BM1308, RGB-Net TD1101 and DFG RTG ProMoAge 2155. 


\section{Acknowledgements}

We thank Michaela Kirstein and Sabine Schrötter for their excellent technical assistance.

\section{References}

Adastra KL, Chi MM, Riley JK \& Moley KH 2011 A differential autophagic response to hyperglycemia in the developing murine embryon. Reproduction 141 607-615. (doi:10.1530/REP-10-0265)

Ashwell M, Purkins L, Cowen T \& Day KC 1987 Pre- and postnatal development of adipose tissue at four sites in the guinea pig: effect of maternal diet restriction during the second half of pregnancy. Annals of Nutrition and Metabolism 31 197-210. (doi:10.1159/000177269)

Dennis MD, Baum JI, Kimball SR \& Jefferson LS 2011 Mechanism involved in the coordinate regulation of mTORC1 by insulin and amino acids. Journal of Biological Chemistry 286 8287-8296. (doi:10.1074/jbc. M110.209171)

Dulloo AG \& Girardier L 1993 Adaptive role of energy expenditure in modulating body fat and protein deposition during catch-up growth after early undernutrition. American Journal of Clinical Nutrition 58 614-621.

Eckert JJ, Porter R, Watkins AJ, Burt E, Brooks S, Leese HJ, Humpherson PG, Cameron IT \& Fleming TP 2012 Metabolic induction and early responses of mouse blastocyst development programming following maternal low protein diet affecting life-long health. PLOS ONE 7 e52791. (doi:10.1371/journal.pone.0052791)

Felig P, Marliss E, Ohman JL \& Cahill GF Jr 1970 Plasma amino acid levels in diabetic ketoacidosis. Diabetes 19 727-729. (doi:10.2337/diab. 19.10.727)

Fischer B, Chavatte-Palmer P, Viebahn C, Navarrete Santos A \& Duranthon V 2012 Rabbit as a reproductive model for human health. Reproduction 144 1-10. (doi:10.1530/REP-12-0091)

Gangloff Y, Mueller M, Dann S, Svoboda P, Sticker M, Spetz J, Um SH, Brown EJ, Cerighini S, Thomas G et al. 2004 Disruption of the mouse mTOR gene leads to early postimplantationlethality and prohibits embryonic stem cell development. Molecular and Cellular Biology 24 9508-9516. (doi:10.1128/MCB.24.21.9508-9516.2004)

González IM, Martin PM, Burdsal C, Sloan JL, Mager S, Harris T \& Sutherland AE 2011 Leucine and arginine regulate trophoblast motility through mTOR-dependent and independent pathways in the preimplantation mouse embryo. Developmental Biology 361 286-300.

Guertin D, Stevens D, Thoreen C, Burds A, Kalaany N, Moffat J, Brown M, Fitzgerald KJ \& Sabatini DM 2006 Ablation in mice of the mTORC components raptor, rictor, or $\mathrm{mLST} 8$ reveals that $\mathrm{mTORC} 2$ is required for signaling to Akt-FOXO and PKC, but not S6K1. Developmental Cell 11 859-871. (doi:10.1016/j.devcel.2006.10.007)

Gürke J, Hirche F, Thieme R, Haucke E, Schindler M, Stangl GI, Fischer B \& Navarrete Santos A 2015 Maternal diabetes leads to adaptation in embryonic amino acid metabolism during early pregnancy. PLOS ONE 10 e0127465.

Hay N 2005 The Akt-mTOR tango and its relevance to cancer. Cancer Cell 8 179-183. (doi:10.1016/j.ccr.2005.08.008)

Heywood WE, Mian N, Milla PJ \& Lindley KJ 2004 Programming of defective rat pancreatic $\beta$-cell function in offspring from mothers fed a low-protein diet during gestation and the suckling periods. Clinical Science 107 37-45. (doi:10.1042/CS20030350)

Hosokawa N, Hara T, Kaizuka T, Kishi C, Takamura A, Miura Y, Iemura S-I, Natsume T, Takehana K, Yamada N et al. 2009 Nutrient-dependent mTORC1 association with the ULK-Atg13-FIP200 complex required for autophagy. Molecular Biology of the Cell 20 1981-1991. (doi:10.1091/ mbc.E08-12-1248)

Inoki K, Zhu T \& Guan K 2003 TSC2 mediates cellular energy response to control cell growth and survival. Cell 115 577-590. (doi:10.1016/S00928674(03)00929-2)

Khamzina L, Veilleux A, Bergeron S \& Marette A 2004 Increased activation of the mTOR pathway in liver and skeletal muscle of obese rats: possible involvement in obesity-linked insulin resistance. Endocrinology 146 1473-1481. (doi:10.1210/en.2004-0921)
Kim JE \& Chen J 2004 Regulation of peroxisome proliferator-activated receptor-gamma activity by mammalian target of rapamycin and amino acids in adipogenesis. Diabetes 53 2748-2756. (doi:10.2337/diabetes. 53.11.2748)

Kim JY, Burghardt RC, Wu G, Johnson GA, Spencer TE \& Bazer FW $2011 b$ Select nutrients in the ovine uterine lumen. IX. Differential effects of arginine, leucine, glutamine, and glucose on interferon tau, ornithine decarboxylase, and nitric oxide synthase in the ovine conceptus. Biology of Reproduction 84 1139-1147. (doi:10.1095/biolreprod.110.088153)

Kimball SR \& Jefferson LS 2006 Signaling pathways and molecular mechanisms through which branched-chain amino acids mediate translational control of protein synthesis. Journal of Nutrition 136 227S-231S.

Kwon GK, Marshall CA, Pappan KL, Remedi MS \& McDaniel ML 2004 Signaling elements involved in the metabolic regulation of mTOR by nutrients, incretins, and growth factors in islets. Diabetes 53 (Suppl 3) S225-S232. (doi:10.2337/diabetes.53.suppl_3.S225)

Langley SC, Browne RF \& Jackson AA 1994 Altered glucose tolerance in rats exposed to maternal low protein diets in utero. Comparative Biochemistry and Physiology 109 223-229. (doi:10.1016/0300-9629 (94)90124-4)

Langley-Evans SC, Welham SJ, Sherman RC \& Jackson AA 1996 Weanling rats exposed to maternal low-protein diets during discrete periods of gestation exhibit differing severity of hypertension. Clinical Science $\mathbf{9 1}$ 607-615. (doi:10.1042/cs0910607)

Laplante M \& Sabatini DM 2009 mTOR signaling at a glance. Journal of Cell Science 122 3589-3594. (doi:10.1242/jcs.051011)

Lee SJ, Kim JY, Nogueiras R, Linares JF, Perez-Tilve D, Jung DY, Ko HJ, Hofmann SM, Drew A, Leitges M et al. 2010 PKC inflammation in the nonhematopoietic compartment is critical for obesity-induced glucose intolerance. Cell Metabolism 12 65-77. (doi:10.1016/j.cmet.2010.05.003)

Leese HJ 2002 Quiet please, do not disturb: A hypothesis of embryo metabolism and viability. BioEssays 24 845-849.

Levine B \& Yuan A 2005 Autophagy in cell death: an innocent convict? Journal of Clinical Investigation 115 2679-2688. (doi:10.1172/JCI26390)

Lin TA, Kong X, Haystead TA, Pause A, Belsham G, Sonenberg N \& Lawrence JC Jr 1994 PHAS-I as a link between mitogen-activated protein kinase and translation initiation. Science 266 653-656. (doi:10.1126/ science.7939721)

Lynch C, Patson B, Anthony J, Vayal A, Jefferson L \& Vary T 2002 Leucin is a direct-acting nutrient signal that regulates protein synthesis in adipose tissue. American Journal of Physiology, Endocrinology and Metabolism 283 E503-E513. (doi:10.1152/ajpendo.00084.2002)

Ma XM \& Blenis J 2009 Molecular mechanisms of mTOR-mediated translational control. Nature Reviews Molecular Cell Biology 10 307-318. (doi:10.1038/nrm2672)

Martin PM \& Sutherland AE 2001 Exogenous amino acids regulate trophectoderm differentiation in the mouse blastocysts through an mTOR-dependent pathway. Developmental Biology 240 182-193. (doi:10.1006/dbio.2001.0461)

Martin P, Sutherland AE \& Van Winkle LJ 2003 Amino acid transport regulates blastocyst implantation. Biology of Reproduction 69 1101-1108. (doi:10.1095/biolreprod.103.018010)

Maurer R 1978 Advances in rabbit embryo culture. In: Methods in Mammalian Reproduction, Ed J C Daniel pp 259-272. New York, NY: Academic Press.

Meyer RA 2002 Encyclopedia of Molecular Cell Biology and Molecular Medicine, Vol 2, 2nd edn. Wiley-VCH.

Hosokawa N, Hara T, Kaizuka T, Kishi C, Takamura A, Miura Y, lemura S, Natsume T, Takehana K, Yamada N et al. 2009 Nutrient-dependent mTORC1 association with the ULK1-Atg13-FIP200 complex required for autophagy. Molecular Biology of the Cell 20 1981-1991. (doi:10.1091/ mbc.E08-12-1248)

Pause A, Belsham GJ, Gingras AC, Donzé O, Lin TA, Lawrence JC Jr \& Sonenberg N 1994 Insulin-dependent stimulation of protein synthesis by phosphorylation of a regulator of $5^{\prime}$-cap function. Nature 371 762-767. (doi:10.1038/371762a0)

Polak P, Cybulski N, Feige JN, Auwerx J, Rüegg MA \& Hall MN 2008 Adipose-specific knockout of raptor results in lean mice with enhanced mitochondrial respiration. Cell Metabolism 8 399-410. (doi:10.1016/j. cmet.2008.09.003) 
Porstmann T, Santos CR, Griffiths B, Cully M, Wu M, Leevers S, Griffiths JR, Chung YL \& Schulze A 2008 SREBP activity is regulated by mTORC1 and contributes to Akt-dependent cell growth. Cell Metabolism 8 224-236. (doi:10.1016/j.cmet.2008.07.007)

Ramin N, Thieme R, Fischer S, Schindler M, Schmidt T, Fischer B \& Navarrete Santos A 2010 Maternal diabetes impairs gastrulation and insulin and IGF-I receptor expression in rabbit blastocysts. Endocrinology 151 4158-4167. (doi:10.1210/en.2010-0187)

Richter JD \& Sonenberg N 2005 Regulation of cap-dependent translation by elF4E inhibitory proteins. Nature 433 477-480. (doi:10.1038/ nature03205)

Rodriguez A, Duran A, Selloum M, Champy M-F, Diez-Guerra FJ, Flores JM, Serrano M, Auwerx J, Diaz-Meco MT \& Moscat J 2006 Mature-onset obesity and insulin resistance in mice deficient in the signalling adapter p62. Cell Metabolism 3 211-222. (doi:10.1016/j. cmet.2006.01.011)

Schindler M, Pendzialek M, Navarrete Santos A, Plösch T, Seyring S, Gürke J, Haucke E, Knelangen JM, Fischer B \& Santos AN 2013 Maternal diabetes leads to unphysiological high lipid accumulation in rabbit preimplantation embryos. Endocrinology 155 1498-1509. (doi:10.1210/ en.2013-1760)

Singh R, Xiang Y, Wang Y, Baikati K, Cuervo AM, Luu YK, Tang Y, Pessin JE, Schwartz GJ \& Czaja MJ 2009 Autophagy regulates adipose mass and differentiation in mice. Journal of Clinical Investigation 119 3329-3339. (doi:10.1172/JCl35541)

Shamji A, Nghiem P \& Schreiber S 2003 Integration of growth factor and nutrient signaling: implications for cancer biology. Molecular Cell 12 271-280. (doi:10.1016/j.molcel.2003.08.016)

Shwa RJ \& Cantley LC 2006 Ras, $\mathrm{PI}(3) \mathrm{K}$ and mTOR signaling controls tumour cell growth. Nature $\mathbf{4 4 1}$ 424-430. (doi:10.1038/nature04869)
Stitzel ML \& Seydoux G 2007 Regulation of the oocyte-to-zygote transition. Science 316 407-408. (doi:10.1126/science.1138236)

Thieme R, Schindler M, Ramin N, Fischer S, Mühleck B, Fischer B \& Navarrete Santos A 2012 Insulin growth factor adjustment in preimplantation rabbit blastocysts and uterine tissue in response to maternal type 1 diabetes. Molecular and Cellular Endocrinology $\mathbf{3 4 8}$ 112-119. (doi:10.1016/j.mce.2011.07.044)

Tsukamoto S, Kuma A, Murakami M, Kishi C, Yamamoto A \& Mizushima N 2008 Autophagy is essential for preimplantation development of mouse embryos. Science 321 117-120. (doi:10.1126/science.1154822)

Um SH, Frigerio $F$, Watanabe $M$, Picard $F$, Joaquin $M$, Sticker $M$, Fumagalli S, Allegrini PR, Kozma SC, Auwerx J et al. 2004 Absence of S6K1 protects against age- and diet-induced obesity while enhancing insulin sensitivity. Nature 431 200-205. (doi:10.1038/nature02866)

Wullschleger S, Loewith R \& Hall MN 2006 TOR signalling in growth and metabolism. Cell 124 471-484. (doi:10.1016/j.cell.2006.01.016)

Yang X, Yang C, Farberman A, Rideout TC, de Lange CFM, France J \& Fan MZ 2008 The mammalian target of rapamycin-signaling pathway in regulating metabolism and growth. Journal of Animal Science $\mathbf{8 6}$ (Suppl 14) E36-E50.

Zoncu R, Efeyan A \& Sabatini DM 2011 mTOR: from growth signal integration to cancer, diabetes and ageing. Nature Reviews Molecular Cell Biology 12 21-35. (doi:10.1038/nrm3025)

Received 4 November 2015

First decision 22 December 2015

Revised manuscript received 22 January 2016

Accepted 1 February 2016 